\title{
ИНФОРМАТИКА INFORMATICS
}

\author{
L.Zh. Sansyzbay, B.B. Orazbayev \\ L.N. Gumilyov Eurasian National University, Nur-Sultan, Kazakhstan \\ (E-mail: sansyzbaylazzat@gmail.com)
}

\section{The development of the model of the intelligent system on the basis of fuzzy sets for microclimate control of building}

\begin{abstract}
Nowadays, much attention is paid to the creation of favorable conditions for the health and work of people and the microclimate in the design and further operation of buildings. It is necessary to investigate the processes of forming a microclimate in the room to assess the comfort of the microclimate, as well as to determine the required capacity of the equipment of engineering systems. Analytical research methods, methods of mathematical and computer modeling are used as research methods. The methods of analysis and synthesis of automatic control systems, mathematical apparatus of theory of fuzzy logic, the Matlab software environment, the system of visual modeling Simulink, and the system for designing fuzzy systems Fuzzy Logic Toolbox are used for research. The paper presents a model of the room, taking into account the heat loss through the enclosing structures, the model of the air conditioner, the structure of the fuzzy control system, the algorithm of its functioning, input and output variables of the fuzzy controller, the composition of their terms, membership functions, the formed complete database of rules. On the basis of research methods, the actual scientific and practical problem of developing an intelligent control system for the formation of the comfort microclimate of the building is solved.
\end{abstract}

Keywords: intelligent system, building microclimate, simulation, fuzzy inference system, fuzzy logic, linguistic rules, air conditioning system.

\section{Introduction}

The favorable microclimate is created by the building's engineering systems, such as heating, ventilation and air conditioning.

Using of computer simulation and the choice of an adequate microclimate model reduce labor costs in the design of the above systems.

At present, in the domestic and foreign literature, a large number of articles are devoted to research models and methods of microclimate control in buildings [1-15].

At the same time, there are no publications of scientists where research and development of a control system would be conducted taking into account the characteristics of the room and all disturbing influences.

All microclimate control models are divided into three classes: white, black and gray box models [16; 225].

Analysis of the works of foreign authors showed that the most used models are models based on the comfort index PMV/PDD (23\%), models based on fuzzy logic (22\%) and learning models $(20 \%)$.

The advantages and disadvantages of models of three classes are considered in the work [16; 226, 227].

Despite the shortcomings, the considered models have the ability to maintain thermal comfort in the building. But the most effective for solving this problem is the use of fuzzy systems [17-19]. 
Fuzzy systems are suitable for maintaining microclimate parameters in both industrial and office premises, for a number of reasons:

- the ability to control nonlinear systems with dynamically changing parameters, even in the absence of a complete priori information about the control object;

- the use of expert knowledge in a particular subject area and their representation in the form of linguistic variables that are close to human perception;

- tangible improvements in performance of control processes in the case of application of fuzzy controllers.

The purpose of this article is to research and develop the building microclimate control system based on fuzzy logic (fuzzy logic is a branch of mathematics that is a generalization of classical logic and set theory, based on the concept of fuzzy set), taking into account all disturbing influences and characteristics of room, as well as its approbation (checking the adequacy of the system by conducting a simulation).

\section{Development of Matlab model for fuzzy temperature control system in the room}

Temperature control is one of the major factors influencing microclimate in both industrial and residential buildings. Therefore, the modeling of the control system based on the fuzzy controller is tested on the basis of the room temperature control loop.

This control loop consists of the following blocks (Fig. 1):

- Block «Set temperature» establishes the desired temperature in the room.

- Block «Fuzzy controller» represents a model of the fuzzy controller, which is formed using Fuzzy Logic Toolbox package, designed specifically for constructing the fuzzy expert and / or control systems.

- Using «Room model» block, heat losses through constructions enclosing room are considered.

- Block «Conditioner Model». In buildings, the conditioner is installed, which can operate in two modes: a heating or cooling.

The system operates in the following way: the difference between the set and the current room temperature is provided to the input of the controller. Based on the generated base of rules, the controller provides an output signal to the conditioner, which includes the heating or the cooling mode with the appropriate productivity based on the error value.

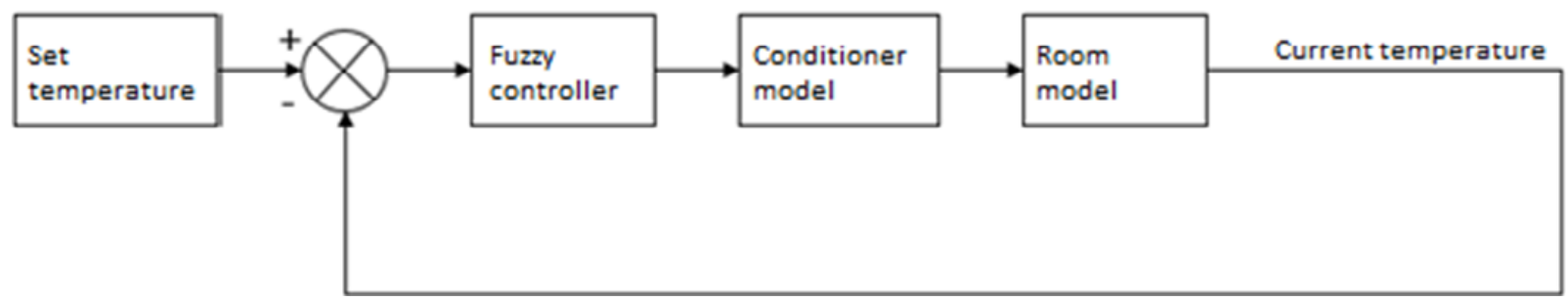

Figure 1. Temperature control loop block diagram

\section{Determination and calculation of heat loss through the enclosing surfaces}

Heat losses occur in the room through the walls, windows, ceiling and floor.

The following is the general formula for the calculation of heat loss:

$$
Q_{\text {heatloss }}=Q_{\text {walls }}+Q_{\text {windows }}+Q_{\text {ceiling }}+Q_{\text {floor }},
$$

where, $Q_{\text {walls }}, Q_{\text {windows }}, Q_{\text {ceiling }}, Q_{\text {floor }}$ - heat loss through exterior walls, windows, ceiling and floor, respectively.

The premise with the following characteristics is taken as an example for the calculation of heat losses.

The premise is located on the first floor of the business center.

The dimensions of the premises:

- Length - $8 \mathrm{~m}$;

- Width - $5 \mathrm{~m}$;

- Ceiling height $-3 \mathrm{~m}$.

The premise consists of two external walls, one of which has two windows with the following dimensions $(\mathrm{WxH}): 1.45 \times 1.5 \mathrm{~m}$ and two internal walls, one of which has a doorway. 
Characteristics of exterior walls.

Exterior wall construction:

- brickwork with a thickness of $640 \mathrm{~mm}$ (thermal conductivity is $0,7 \mathrm{kcal} / \mathrm{m} \cdot \mathrm{hour} \cdot{ }^{\circ} \mathrm{C}$ );

- internal plaster with a thickness of $15 \mathrm{~mm}$ (thermal conductivity is $0,6 \mathrm{kcal} / \mathrm{m} \cdot \mathrm{hour} \cdot{ }^{\circ} \mathrm{C}$ ).

Heat transfer resistance $R_{i n}$ for internal surfaces of walls, floors, as well as ceilings with a smooth surface is $0.133 \mathrm{~m}^{2} \cdot$ hour $\cdot{ }^{\circ} \mathrm{C} / \mathrm{kcal}$. The heat transfer resistance for $R_{e x}$ outer surfaces which are contacted with the outside air (exterior walls) is $0.5 \mathrm{~m}^{2} \cdot$ hour $\cdot{ }^{\circ} \mathrm{C} / \mathrm{kcal}$.

Window construction: plastic profile frame (heat transfer coefficient of plastic profile $0.2 \mathrm{~W} / \mathrm{m}^{2}{ }^{\circ} \mathrm{C}$ ), double glazing (heat transfer resistance coefficient $0.51 \mathrm{~m}^{2} \cdot{ }^{\circ} \mathrm{C} / \mathrm{W}$, heat transfer coefficient $1.96 \mathrm{~W} / \mathrm{m}^{2} \cdot{ }^{\circ} \mathrm{C}$ ).

Heat losses through the wall are determined according to the expression [20]:

$$
Q_{\text {walls }}=k_{\text {walls }} \cdot S_{\text {walls }} \cdot\left(t_{\text {in }}-t_{\text {out }}\right),
$$

where, $Q_{\text {walls }}$ - heat loss through exterior walls, $\mathrm{kcal} / \mathrm{h} ; k_{\text {walls }}$ - heat transfer coefficient of the wall, $\mathrm{kcal} / \mathrm{m}^{2}$.hour $\cdot{ }^{\circ} \mathrm{C} ; S_{\text {walls }}$ - an area of the wall, $\mathrm{m}^{2} ; t_{i n}$ - internal temperature of the room, ${ }^{\circ} \mathrm{C} ; t_{\text {out }}$ - outside temperature, ${ }^{\circ} \mathrm{C}$.

Heat transfer coefficient of the wall $k_{\text {walls }}$ is calculated by formula $[21 ; 55]$ :

$$
k_{\text {walls }}=1 / R_{c},
$$

where, $R_{c}$ - heat resistance of enclosure construction $\mathrm{m}^{2} \cdot$ hour $\cdot{ }^{\circ} \mathrm{C} / \mathrm{kcal}$.

Since the wall is a multilayered enclosure, the value $R_{c}$ is determined by the formula [21;55]:

$$
R_{c}=R_{i n}+R_{1}+R_{2}+\ldots R_{e x},
$$

where, $R_{\text {in }}$ - heat resistance at the inner surface of the enclosure; $R_{1}, R_{2}$ - thermal resistance of the individual layers of enclosure; $R_{e x}$ - heat resistance at the outer surface of the enclosure.

Thermal resistance of homogeneous enclosure or layer constituting the multilayer enclosures is calculated by the formula $[21 ; 32]$ :

$$
R=\delta / \lambda
$$

where, $\delta$ - layer thickness, $\mathrm{m} ; \lambda$ - thermal conductivity of the material, kcal $/ \mathrm{m} \cdot \mathrm{hour} \cdot{ }^{\circ} \mathrm{C}$.

Applying formulas 3 and 4 , the heat transfer resistance of external walls is calculated:

$$
R_{c}=0.133+0.015 / 0.6+0.64 / 0.7+0.05=1.12 m^{2} \cdot \text { hour } \cdot{ }^{\circ} \mathrm{C} / \text { kcal } .
$$

Heat transfer coefficient of exterior walls:

$$
k_{\text {walls }}=1 / 1.12=0.89 \mathrm{kcal} / \mathrm{m}^{2} \cdot \text { hour } \cdot{ }^{\circ} \mathrm{C} .
$$

$1 \mathrm{kcal}=4.19 \mathrm{~J}$, then $k_{\text {walls }}=3730 \mathrm{~J} / \mathrm{m}^{2} \cdot$ hour $\cdot{ }^{\circ} \mathrm{C}$.

Heat transfer coefficient of the ceiling and floor are calculated similarly heat transfer coefficient of exterior walls.

Heat loss through the window openings are determined according to the expression [20]:

$$
Q_{\text {windows }}=k_{\text {windows }} \cdot S_{\text {windows }} \cdot\left(t_{\text {in }}-t_{\text {out }}\right),
$$

where $Q_{\text {windows }}$ - heat loss through windows, W; $k_{\text {windows }}$ - heat transfer coefficient of windows $\left(\mathrm{W} / \mathrm{m}^{2} .{ }^{\circ} \mathrm{C}\right)$; $S_{\text {windows }}$ - the area of windows, $\mathrm{m}^{2}$.

The heat transfer coefficient of windows $k_{\text {windows }}$ calculated by the following formula [22]:

$$
k_{\text {windows }}=\frac{k_{g l} S_{g l}+k_{f} S_{f}}{S_{t}},
$$

where $k_{g l}$ - heat transfer coefficient of the glazing unit, $\mathrm{W} /\left(\mathrm{m}^{2} \cdot{ }^{\circ} \mathrm{C}\right) ; S_{g l}$ - glazing area, $\mathrm{m}^{2} ; k_{f}$ - heat transfer coefficient of frame (plastic profile), $\mathrm{W} /\left(\mathrm{m}^{2} \cdot{ }^{\circ} \mathrm{C}\right) ; S_{f}$ - frame area, $\mathrm{m}^{2} ; S_{t}$ - window area, $\mathrm{m}^{2}$.

The heat transfer coefficient of windows $k_{\text {windows }}$ :

$$
k_{\text {windows }}=\frac{1.96 \cdot 1.5525+0.2 \cdot 06225}{2.175}=1.46 \mathrm{~W} / \mathrm{m}^{2} \cdot{ }^{\circ} \mathrm{C} .
$$

The heat transfer coefficient of two windows $k_{\text {windows }}=2.92 \mathrm{~W} /\left(\mathrm{m}^{2} \cdot{ }^{\circ} \mathrm{C}\right)$;

$1 \mathrm{~W}=3600 \mathrm{~J} /$ hour, then $k_{\text {windows }}=10512 \mathrm{~J} / \mathrm{m}^{2} \cdot$ hour $\cdot{ }^{\circ} \mathrm{C}$. 


\section{Development of fuzzy controller for temperature control loop in the room}

Input variable of fuzzy controller is the difference between set and current temperatures. The output parameter is the corresponding signal to the actuator of conditioner. Terms and data for constructing membership functions of the input and output variables are presented in Tables 1, 2 .

The structure of the model of the fuzzy controller is shown in Figure 2.

Terms of variable «Temperature difference»

\begin{tabular}{|c|l|c|c|}
\hline No. & Name of the term & Designation of the term & Range, ${ }^{\circ} \mathrm{C}$ \\
\hline 1 & Negative Big & NB & from -22 to -9 \\
\hline 2 & Negative Middle & NM & from -14 to -4 \\
\hline 3 & Negative Small & NS & from -9 to 0 \\
\hline 4 & Zero & Z & from -4 to 4 \\
\hline 5 & Positive Small & PS & from 0 to 8 \\
\hline 6 & Positive Middle & PM & from 3 to 13 \\
\hline 7 & Positive Big & PB & from 8 to 17 \\
\hline
\end{tabular}

Table 2

Terms of variable «Heater (Cooler)»

\begin{tabular}{|c|l|c|c|}
\hline No. & Name of the term & Designation of the term & Range, $\%$ \\
\hline 1 & Stop & ST & 0 \\
\hline 2 & Low Power & LP & $0-30$ \\
\hline 3 & Average Power & AP & $30-60$ \\
\hline 4 & High Power & HP & $60-100$ \\
\hline
\end{tabular}

Table 3 shows the formed base of rules.

Table 3

The rule base of fuzzy temperature control system in the room

\begin{tabular}{|c|l|c|c|}
\hline No. & $\begin{array}{c}\text { If the temperature } \\
\text { difference is important }\end{array}$ & \multicolumn{2}{|c|}{ Then the conditioner is operating in the mode of } \\
\hline & & cooling & heating \\
\hline 1 & Negative Big & At full power & Off \\
\hline 2 & Negative Middle & At average power & Off \\
\hline 3 & Negative Small & At low power & Off \\
\hline 4 & Zero & Off & At low power \\
\hline 5 & Positive Small & Off & At average power \\
\hline 6 & Positive Middle & Off & At full power \\
\hline 7 & Positive Big & Off & \\
\hline
\end{tabular}




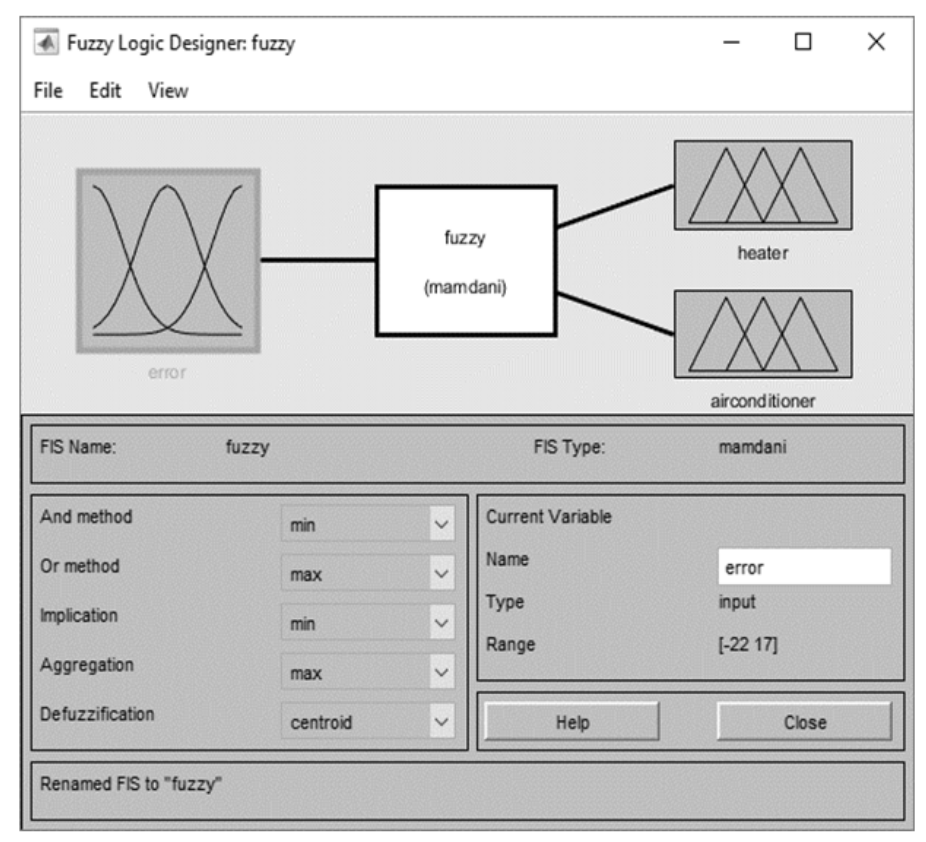

Figure 2. The structure of the model of the fuzzy controller

At the next stage, the verification of the adequacy of the developed control system based on a fuzzy controller for temperature control loop have produced in Simulink package in Matlab software environment (Fig. 3).

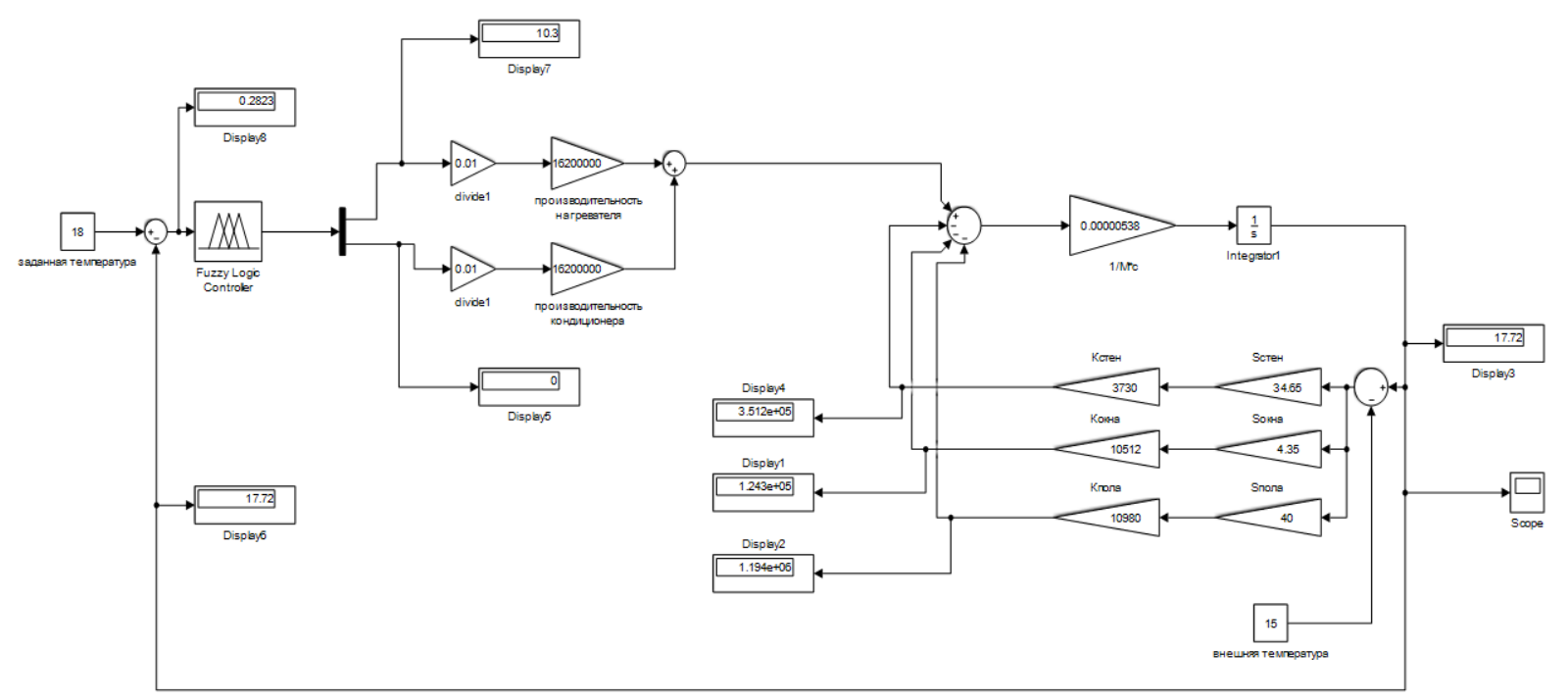

Figure 3. The fuzzy microclimate system for temperature control loop

Set temperature of Tset $=18^{\circ} \mathrm{C}$ is defined for modeling. According to the simulation results, the temperature difference is equal to $0.2823{ }^{\circ} \mathrm{C}$. In response to this difference, the controller initiates a control signal to the conditioner for turning on the heating mode with performance of $10.3 \%$ (Fig. 4). This scenario indicates that rule № 5 is implemented, when the error has a positive small value (it is slightly cold in the premise), it is required to turn off the cooling and turn on the heating at low power. The modeling results show that the fuzzy controller is suitable for maintaining microclimate parameters at the required level (Fig. 5). 


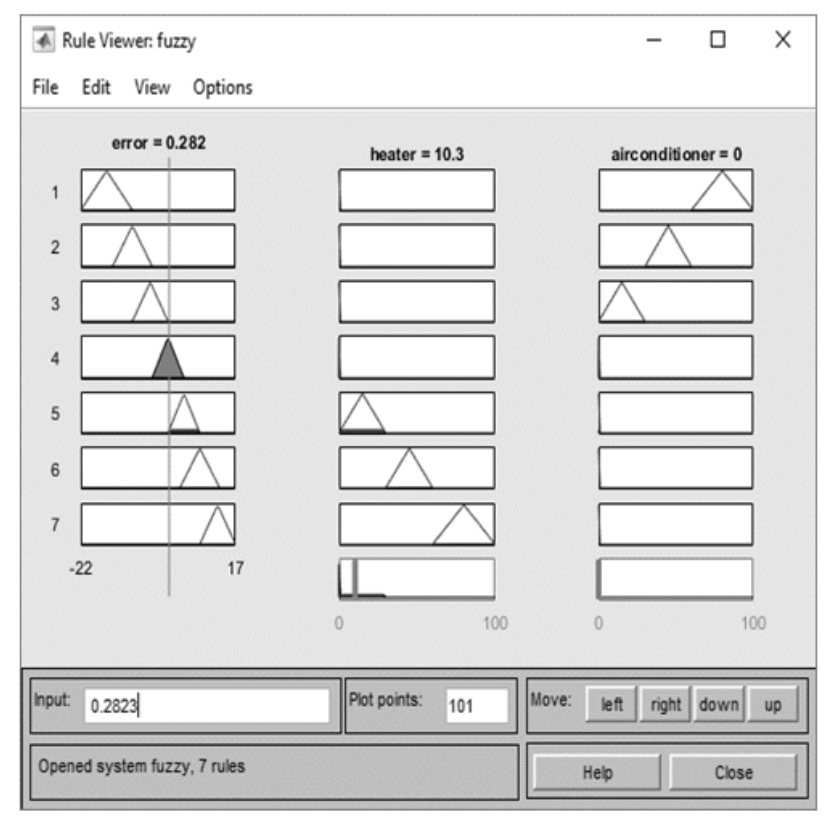

Figure 4. The value of the control signal for $0.2823^{\circ} \mathrm{C}$ temperature difference

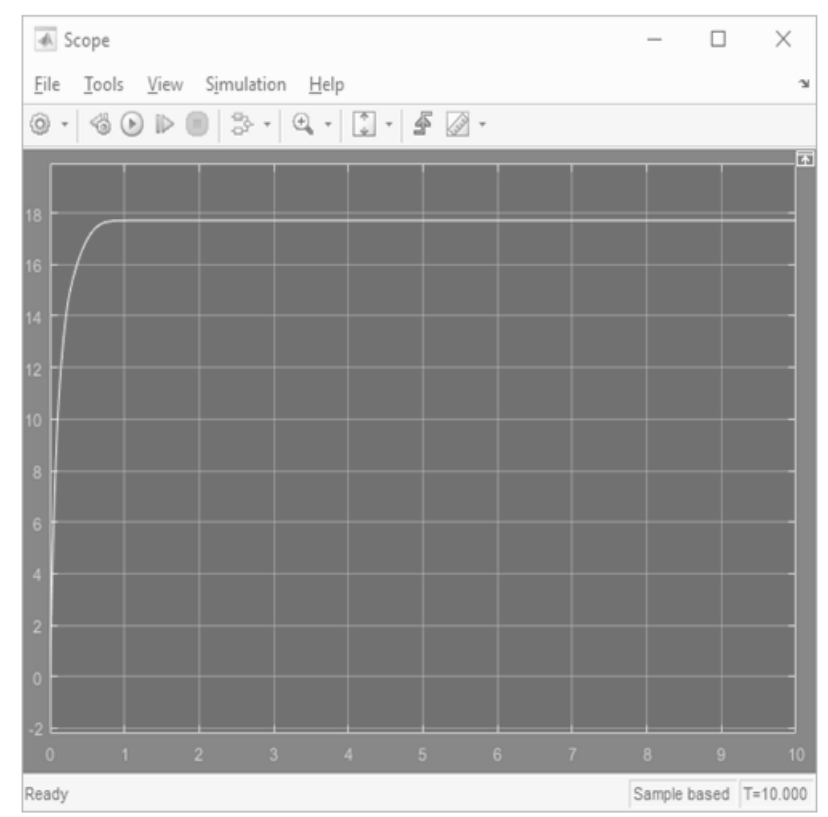

Figure 5. Plot of current temperature based on simulation results

\section{Main result}

The research has produced the following results, which have a scientific and practical importance:

1. The analysis of the microclimate control models has performed.

2. Heat loss through the enclosing surfaces (walls, windows, ceiling and floor) of the room have calculated in the article.

3. The model of fuzzy controller has developed using Fuzzy Logic Toolbox package.

4. The simulation of developed control system taking into account the characteristics of the premise has conducted in Simulink package of Matlab software environment.

5. The research results have demonstrated that the developed intelligent microclimate control system of buildings based on the fuzzy logic ensures the maintenance of microclimate parameters (temperature) at the required level. 
The further researches in this direction refer to the exploring the possibility of using a fuzzy controller to optimize the performance of various climatic equipment (heater, humidifier, fan plants, etc.).

\section{References}

1 Сансызбай Л.Ж. Интеллектуальная система управления процессом формирования микроклимата в помещении / Л.Ж. Сансызбай, Б.Б. Оразбаев // Вест. ЕНУ им. Л.Н. Гумилева. Сер. естеств.-техн. наук. - 2017. - №4(119). - С. 161-169.

2 Бобриков Д.А. Многоуровневая автоматизированная система управления микроклиматом на основе нечеткой логики: дис. ... канд. техн. наук: 05.13.06 - «Автоматизация и управление технологическими процессами и производствами (по отраслям)» / Д.А. Бобриков. - М., 2017. - 154 с.

3 Пешко М.С. Адаптивная система управления параметрами микроклимата процессов производства и хранения пищевых продуктов: дис. ... канд. техн. наук: 05.13 .06 - «Автоматизация и управление технологическими процессами и производствами (по отраслям)» / М.С. Пешко. - М., 2015. - 200 с.

4 Савосин С.И. Интеллектуальная система контроля влажности и температуры воздуха в теплице: дис. ... канд. техн. наук: 05.13.06 - «Автоматизация и управление технологическими процессами и производствами (по отраслям)»/ С.И. Савосин. - М., 2009. - 132 с.

5 Hasim N. Intelligent room temperature controller system using MATLAB fuzzy logic toolbox / N. Hasim, M.S.M. Aras // International Journal of Science and Research (IJSR). - 2014. - Vol. 3. - P. 1748-1753.

6 Das T.K. Design of A Room Temperature and Humidity Controller Using Fuzzy Logic / T.K. Das, Y. Das // American Journal of Engineering Research (AJER). - 2013. - Vol. 2. - P. 86-97.

7 Alcala R. Fuzzy Rule Reduction and Tuning of Fuzzy Logic Controllers for a HVAC System / R. Alcala, J. Alcala-Fdez, M.J. Gacto, F. Herrera // Journal Fuzzy Applications in Industrial Engineering - 2006. - Vol. 201. - P. 89-117.

8 Calvino F. The control of indoor thermal comfort conditions: introducing a fuzzy adaptive controller / F. Calvino, M.L. Gennusa, G. Rizzo, G. Scaccianoce // Journal Energy and Buildings. - 2004. Vol. 36. - P. 97-102.

9 Eftekhari M. Application of fuzzy control in naturally ventilated buildings for summer conditions / M. Eftekhari, L. Marjanovic // Journal Energy and Buildings. - 2003. - Vol. 35. - P. 645-655.

10 Kolokotsa D. Comparison of the performance of fuzzy controllers for the management of the indoor environment / D. Kolokotsa // Journal Building and Environment. - 2003. - Vol. 38. - P. 1439-1450.

11 Mirinejad H. A review of intelligent control techniques in HVAC systems / H. Mirinejad, K.C. Welch, L. Spicer // Proc. of the IEEE Energytech. - 2012. - P. 1-5.

12 Molina-Solana M. Unifying Fuzzy controller for Indoor Environment Quality / M. Molina-Solana, M. Ros, M. Delgado // Proc.Joint of IFSA World Congress and NAFIPS Annual Meeting (IFSA/NAFIPS). 2013. - P. 1080-1085.

$13 \mathrm{Xu}$ X.N. Intellectual controlling and energy-saving management for terminal equipment of air-conditioning system / X.N. Xu, Y.F. Ding // Building Science. - 2008. - Vol. 24(8). - P. 43-46.

14 Soyguder S. Design and simulation of selftuning pid-type fuzzy adaptive control for an expert hvac system / S. Soyguder, M. Karakose, H. Alli // Expert Systems with Applications. — 2009. — Vol. 36. — P. 4566-4573.

15 Dounis A. Advanced control systems engineering for energy and comfort management in a building environment-a review / A. Dounis, C. Caraiscos // Renewable and Sustainable Energy Reviews. - 2009. - Vol. 13. - P. 1246-1261.

16 Карпенко А.В. Модели управления микроклиматом в помещении / А.В. Карпенко, И.Ю. Петрова // Фундаментальные исследования. - 2016. - № 7(2). - С. 224-229.

17 Zadeh L. Fuzzy sets and systems / L. Zadeh // International Journal of General Systems. - 1990. Vol. 17. - P. 129-138.

18 Takagi T. Fuzzy identification of systems and its applications to modeling and control / T. Takagi, M. Sugeno // IEEE Transactions on Systems, Man and Cybernetics. - 1985. - Vol. 15(1). - P. 116-132.

19 Mamdani E. Application of fuzzy logic to approximate reasoning using linguistic synthesis / E. Mamdani // IEEE Transactions on Computers. - 1977. - Vol. 26(12). - P. 1182-1191. 
20 Пешко М.С. Раскрытая математическая модель микроклимата грибной теплицы / М.С. Пешко // Молодой ученый. - 2011. - № 9. - С. 42-48.

21 Малявина Е.Г. Теплопотери здания / Е.Г. Малявина. - М.: ABOK-ПРЕСС, 2007. - 146 с.

22 СНиП РК 2.04-03-2002. Строительная теплотехника. [Введен в действие от 2003-03-01]. - Астана: КАЗГОР, 2002. $-54 \mathrm{c}$.

\author{
Л.Ж. Сансызбай, Б.Б. Оразбаев
}

\title{
Ғимараттың микроклиматын интеллектуалды басқару жүйесінің моделін айқын емес жиындар теориясы негізінде құру
}

\begin{abstract}
Қазіргі таңда ғимаратты жобалау және одан әрі пайдалану кезінде адамдардың денсаулығы мен жұмысы үшін қолайлы жағдай жасауға, микроклиматқа үлкен көңіл бөлінеді. Микроклиматтың жайлылығын бағалау, сондай-ақ инженерлік жүйелер жабдықтарының қажетті жұмыс қуатын анықтау үшін үй-жайлардың микроклиматының қалыптасу процестерін зерттеу қажет. Зерттеу әдістері ретінде аналитикалық, математикалық және компьютерлік модельдеу әдістері қолданылды. Зерттеу жүргізу үшін автоматты басқару жүйелерін талдау және синтездеу әдістері, анық емес логика теориясының математикалық аппараты, Matlab қолданбалы бағдарламалар пакеті, Simulink визуальды модельдеудің графикалық жүйесі, Fuzzy Logic Toolbox анық емес жүйелерін әзірлеуге арналған жүйесі қолданылды. Жұмыс барысында қоршау конструкциялары арқылы жылу шығынын ескеретін үйжай моделі, кондиционер моделі, басқару жүйесінің құрылымы, оның жұмыс істеу алгоритмі, анық емес реттегіштің кіріс және шығыс айнымалылары, олардың термаларының құрамы, тиістілік функциялары анықталған, ережелердің толық базасы қалыптасқан. Теориялық зерттеу, математикалық және компьютерлік моделдеу жүргізу нәтижесінде үй-жайлардың микроклиматын интеллектуалды басқару жүйесі айқын емес логика базасында құрылып, қазіргі таңдағы өзекті ғылыми-практикалық мәселелердің бірі шешілді.
\end{abstract}

Kiлm сөздер: интеллектуалдық бақылау жүйесі, ғимараттың микроклиматы, айқын емес қорытындылау жүйесі, айқын емес логика, лингвистикалық ережелер, кондиционерлеу жүйесі.

\author{
Л.Ж. Сансызбай, Б.Б. Оразбаев
}

\section{Разработка модели интеллектуальной системы управления микроклиматом здания на основе теории нечетких множеств}

На сегодняшний день при проектировании и дальнейшей эксплуатации зданий большое внимание уделяется созданию благоприятных условий для здоровья и работы людей, микроклимата. Для оценки комфортности микроклимата, а также определения требуемой мощности работы оборудования инженерных систем необходимо исследование процессов формирования микроклимата в помещении. В качестве методов исследования применены аналитические методы исследования, методы математического и компьютерного моделирования. Для проведения исследований использованы методы анализа и синтеза систем автоматического управления, математический аппарат теории нечеткой логики, пакет прикладных программ Matlab, система визуального моделирования Simulink, система для разработки нечетких систем Fuzzy Logic Toolbox. В работе представлена модель помещения, учитывающая теплопотери через ограждающие конструкции, модель кондиционера, определены структура нечеткой системы управления, алгоритм ее функционирования, входные и выходные переменные нечеткого регулятора, состав их термов, функций принадлежности, сформирована полная база правил. На основании проведения теоретического исследования, математического и компьютерного моделирований решена актуальная научно-практическая задача разработки интеллектуальной системы управления процессами формирования микроклимата помещений, реализуемой на базе теории нечеткой логики.

Ключевые слова: интеллектуальная система, микроклимат здания, система нечеткого вывода, нечеткая логика, лингвистические правила, система кондиционирования. 


\section{References}

1 Sansyzbay, L.Zh. \& Orazbayev, B.B. (2017). Intellektualnaia sistema upravleniia protsessom formirovaniia mikroklimata v pomeshchenii [Intelligent control systems indoor climate]. Vestnik ENU imeni L.N. Gumileva. Seriia estestvenno-tekhnicheskikh nauk - Bulletin of the L.N.Gumilyov Eurasian National University. Natural and technical Series, 4(119), 161-169 [in Russian].

2 Bobrikov, D.A. (2017). Mnohourovnevaia avtomatizirovannaia sistema upravleniia mikroklimatom na osnove nechetkoi lohiki [Multi-level automated climate control system based on fuzzy logic]. Candidate's thesis. Moscow [in Russian].

3 Peshko, M.S. (2015). Adaptivnaia sistema upravleniia parametrami mikroklimata protsessov proizvodstva i khraneniia pishchevykh produktov [Adaptive control system of microclimate parameters of food production and storage processes]. Candidate's thesis. Moscow [in Russian].

4 Savosin, S.I. (2009). Intellektualnaia sistema kontrolia vlazhnosti i temperatury vozdukha v teplitse [Intellectual control system of humidity and air temperature in the greenhouse]. Candidate's thesis. Moscow [in Russian].

5 Hasim, N., \& Aras, M.S.M. (2014). Intelligent room temperature controller system using MATLAB fuzzy logic toolbox. International Journal of Science and Research (IJSR), 3, 1748-1753.

6 Das, T.K., \& Das, Y. (2013). Design of A Room Temperature And Humidity Controller Using Fuzzy Logic. American Journal of Engineering Research (AJER), 2, 86-97.

7 Alcala, R., Alcala-Fdez, J., Gacto, M.J., \& Herrera, F. (2006). Fuzzy Rule Reduction and Tuning of Fuzzy Logic Controllers for a HVAC System. Journal Fuzzy Applications in Industrial Engineering, 201, 89-117.

8 Calvino, F., Gennusa, M.L., Rizzo, G., \& Scaccianoce, G. (2004). The control of indoor thermal comfort conditions: introducing a fuzzy adaptive controller. Journal Energy and Buildings, 36, 97-102.

9 Eftekhari, M., \& Marjanovic, L. (2003). Application of fuzzy control in naturally ventilated buildings for summer conditions. Journal Energy and Buildings, 35, 645-655.

10 Kolokotsa, D. (2003). Comparison of the performance of fuzzy controllers for the management of the indoor environment. Journal Building and Environment, 38, 1439-1450.

11 Mirinejad, H., Welch, K.C., \& Spicer, L. (2012). A review of intelligent control techniques in HVAC systems. Proceedings of the IEEE Energytech, 1-5.

12 Molina-Solana, M., Ros, M., \& Delgado, M. (2013). Unifying Fuzzy controller for Indoor Environment Quality. Proceedings of Joint of IFSA World Congress and NAFIPS Annual Meeting (IFSA/NAFIPS), 1080-1085.

$13 \mathrm{Xu}, \mathrm{X} . \mathrm{N} .$, \& Ding, Y.F. (2008). Intellectual controlling and energy-saving management for terminal equipment of air-conditioning system. Building Science, 24(8), 43-46.

14 Soyguder, S., Karakose, M., \& Alli, H. (2009). Design and simulation of selftuning pid-type fuzzy adaptive control for an expert hvac system. Expert Systems with Applications, 36(3), 4566-4573.

15 Dounis, A., \&, Caraiscos, C. (2009). Advanced control systems engineering for energy and comfort management in a building environment-a review. Renewable and Sustainable Energy Reviews,13, 1246-1261.

16 Karpenko, A.V., \& Petrova, I.Iu. (2016). Modeli upravleniia mikroklimatom v pomeshchenii [Microclimate control models]. Fundamentalnye issledovaniia- Fundamental research, 7(2), 224-229 [in Russian].

17 Zadeh, L. (1990). Fuzzy sets and systems. International Journal of General Systems, 17, 129-138.

18 Takagi, T., \& Sugeno, M. (1985). Fuzzy identification of systems and its applications to modeling and control. IEEE Transactions on Systems, Man and Cybernetics, 15(1), 116-132.

19 Mamdani, E. (1977). Application of fuzzy logic to approximate reasoning using linguistic synthesis. IEEE Transactions on Computers, 26(12), 1182-1191.

20 Peshko, M.S. (2011). Raskrytaia matematicheskaia model mikroklimata hribnoi teplitsy [The disclosed mathematical model of the microclimate in the mushroom greenhouses]. Molodoi uchenyi - Young scientist, 9, 42-48 [in Russian].

21 Maliavina, E. G. (2007). Teplopoteri zdaniia [The heat losses of the building]. Moscow: AVOK-PRESS [in Russian].

22 SNiP RK 2.04-03-2002. Stroitelnaia teplotekhnika [Construction heat engineering] from 1st March of 2003. Astana: KAZGOR [in Russian]. 